\title{
Phylogenetic relationships in the division Lipastromorphi (Coleoptera, Carabidae) of the world as deduced from mitochondrial ND5 gene sequences
}

\author{
Zhi-Hui $\mathrm{Su}^{1 *}$, Yûki Imura ${ }^{2}$, Choong-Gon Kim ${ }^{1 \dagger}$, Munehiro Okamoto ${ }^{3}$ and Syozo Osawa ${ }^{1 \dagger}$ \\ ${ }^{1}$ JT Biohistory Research Hall, 1-1 Murasaki-cho, Takatsuki, Osaka 569-1125, Japan \\ ${ }^{2}$ Shinohara-cho 1249-8, Kohoku-ku, Yokohama, 222-0026, Japan \\ ${ }^{3}$ Department of Laboratory Animal Science, School of Veterinary Medicine, \\ Faculty of Agriculture, Tottori University, Tottori 680-8553, Japan
}

(Received 19 August 2002, accepted 22 January 2003)

\begin{abstract}
Phylogenetic trees have been constructed using mitochondrial ND5 gene sequences of 85 specimens representing 40 species belonging to the division Lipastromorphi of the subtribe Carabina (= genus Carabus s. lat.) of the world. In the trees constructed by several methods, there have been recognized a basal split into two lineages, A and B, which are further divided into 2 (A1 and A2) and 9 (B1-B9) sublineages, respectively. Each sublineage and the clustering of the species in the trees are more or less linked to their geographic distribution. Morphology of the species within A1 or A2 in the lineage A is similar, and the species in most of the sublineages in the lineage $B$ are common in a number of important morphological characters in spite of their long evolutionary histories. Whilst such a morphological stability, considerable morphological changes may be recognized upon or after split of lineages and sublineages. Based on the molecular phylogeny together with the morphological data, the pattern of diversification is discussed.
\end{abstract}

Key words: ground beetles, Lipastromorphi, mitochondrial ND5 gene, phylogeny, evolution, taxonomy

\section{INTRODUCTION}

The carabid ground beetles belonging to the subfamily Carabinae (family Carabidae) consist of two tribes, Cychrini and Carabini. The Carabini are further classified into two subtribes, Carabina and Calosomina. The subtribe Carabina has been generally considered as one genus, Carabus which includes more than 100 subgenera and is classified into 9 divisions. In this paper, subgenera are treated as genera, because we consider such a treatment is more reasonable than the traditional one (see Imura, 2002). The species belonging to the division Lipastromorphi consists of a fairly large group of the ground beetles in the subtribe Carabina (= genus Carabus s. lat.), which are distributed in the Eurasian Continent including some adjunctive islands such as Great Britain,

\footnotetext{
Edited by Naruya Saitou

* Corresponding author. E-mail: su.zhihui@brh.co.jp

$\dagger$ Present address: Lab. of Evolutionary Genetics, National Institute of Genetics, Mishima 411-8540, Japan.

¥ Present address: 2-4-7-1003, Ushita-Asahi, Higashi-ku, Hiroshima 732-0067, Japan.

The nucleotide sequence data reported in this paper will appear in the DDBJ, EMBL, and GenBank nucleotide sequence databases with the accession numbers shown in Table 1.
}

Ireland, Sakhalin, etc. This division has been classified into 6 subgenera (Imura, 1996), including 76 species (Březina, 1999). These beetles receive world-wide admiration from entomologists, as some of them are beautifully colored and like jewels. All the species are hindwingless and so move only by walking. Because of this, conspicuous geographical isolation would have occurred. As a result, they often reveal locality-dependent morphological variations, which make the taxonomy of this group rather difficult.

In the present study, we have constructed phylogenetic trees of the mitochondrial NADH dehydrogenase subunit 5 (ND5) gene from 85 individuals containing 40 species from all the recognized (sub)genera of Lipastromorphi. They are Cyclocarabus, Ophiocarabus, Cryptocarabus, Lipaster, Mimocarabus and Morphocarabus (sensu Imura and Mizusawa, 1996). The phylogenetic analysis has made it possible to suggest an evolutionary history and a reasonable classification of this division that cannot be reached by morphology alone.

\section{MATERIALS AND METHODS}

The specimens analyzed for the ND5 gene sequences 
Table 1. List of the specimens usd in this study

\begin{tabular}{|c|c|c|c|}
\hline \multicolumn{3}{|c|}{ Specimen } & $\begin{array}{l}\text { DDBJ/EMBL/GenBank } \\
\text { Accession no. }\end{array}$ \\
\hline 1 & Cyclocarabus namanganensis & SE. Kazakhstan: Talasskii Alatau Mts., near Dzhabagli., $1100 \mathrm{~m}$ & AB053493 \\
\hline 2 & Cy. martynovi nurbeki & $\begin{array}{l}\text { NW. Kirgiz: S. of Pskem Mts., N. Aktash, Kara-Debe / Tshukur- } \\
\text { Suu Riv., 2500-2700 m }\end{array}$ & АB053494 \\
\hline 3 & Cy. pseudolamprostus & $\begin{array}{l}\text { NW. Kirgiz: S. of Pskem Mts., N. Aktash, Kara-Debe / Tshukur- } \\
\text { Suu Riv., 2500-2700 m }\end{array}$ & AB053495 \\
\hline 4 & Cy. martynovi ssp. (aff. nurbeki) & $\begin{array}{l}\text { NW. Kirgiz: Tshatkal, Kumbel Mts., S.-ES. of Naiza-Tokoi Riv., } \\
\qquad 2700 \mathrm{~m}\end{array}$ & AB053496 \\
\hline 5 & Cy. martynovi ssp. & $\begin{array}{l}\text { NW. Kirgiz: Tshatkal Mts., watershed of Araps \& Sargardon } \\
\text { Rivs., } 2600-3000 \mathrm{~m}\end{array}$ & AB053497 \\
\hline 6 & Cy. pseudolamprostus & $\begin{array}{l}\text { NW. Kirgiz: S. of Pskem Mts., Alma-Sai Riv., N. of Dzhany-Bazar, } \\
\qquad 2400-2900 \mathrm{~m}\end{array}$ & AB053498 \\
\hline 7 & Cy. karaterekensis hemicallisthenes & $\begin{array}{l}\text { NW. Kirgiz: SE. of Tshandalash Mts., Tshakmak-Suu Riv., 3100- } \\
\qquad 3400 \mathrm{~m}\end{array}$ & AB053499 \\
\hline 8 & Cy. karaterekensis ssp. & $\begin{array}{c}\text { NW. Kirgiz: N. of Tshatkal Mts., Aiuu-Tshatshy Riv., } 12 \text { km SE. } \\
\text { Tshakmak-Suu vil., } 2900-3300 \mathrm{~m}\end{array}$ & AB053500 \\
\hline 9 & Cy. martynovi & SE. Kazakhstan: Talasskii Alatau Mts., Dzhabagli & $\mathrm{AB} 053501$ \\
\hline 10 & Cy. minusculus & SE. Kazakhstan: Talasskii Alatau Mts., near Manas & AB053502 \\
\hline 11 & Ophiocarabus striatulus & $\begin{array}{l}\text { NE. Kirgiz: Terskei Ala-Too Mts., Turgen Riv., Kok-Kiya val., } \\
\qquad \begin{array}{l}3000 \mathrm{~m}\end{array}\end{array}$ & AB053503 \\
\hline 12 & Op. striatulus & $\begin{array}{c}\text { NE. Kirgiz: Terskei Ala-Too Mts., upper course of Tiurghen -Aksu } \\
\text { Riv., } 1 \text { km S. of Kok-Kiya, } 2900 \mathrm{~m}\end{array}$ & $\mathrm{AB} 053504$ \\
\hline 13 & Cryptocarabus kadyrbekovi & $\begin{array}{c}\text { SE. Kazakhstan: Transili Alatau Mts., Tshemalghan Riv., near } \\
\text { Dzhandosovo vil., } 1100-1200 \mathrm{~m}\end{array}$ & AB053505 \\
\hline 14 & Cr. lindemanni & $\begin{array}{l}\text { SE. Kazakhstan: N. hoothills of Zailiiskii Alatau Mts., } 27 \mathrm{~km} \text { W. } \\
\text { of Almaty, } 900 \mathrm{~m}\end{array}$ & AB053506 \\
\hline 15 & Cr. subparallelus & SE. Kazakhstan: Almaty, Kok-Tinbe Mts., 900-1000 m & AB053506 \\
\hline 16 & Cr. sacarum & SE. Kazakhstan: Transili Alatau Mts., Kaskelen val., $1200-1300$ m & $\mathrm{AB} 053507$ \\
\hline 17 & Ophiocarabus aeneolus & $\begin{array}{l}\text { SE. Kazakhstan: Zailiiskii Alatau Mts., M. Alma-Atinka Riv., } \\
\qquad 2500 \mathrm{~m}\end{array}$ & АB053508 \\
\hline 18 & Op. aeneolus & $\begin{array}{l}\text { SE. Kazakhstan: Transili Alatau Mts., near Bal Alma, Atinskae } \\
\text { Lake, } 3000-3100 \mathrm{~m}\end{array}$ & AB053509 \\
\hline 19 & Op. latiballioni & NW. China: Xinjiang, SSE. of Tekes, Narat Mts., Ural Riv. & $\mathrm{AB} 053510$ \\
\hline 20 & Op. striatulus & SE. Kazakhstan: Ketmen Mts., Tuiuk, 2000 m & $\mathrm{AB} 053511$ \\
\hline 21 & Op. ballionis & NW. China: Xinjiang, $100 \mathrm{~km}$ E. of Narat, $2500 \mathrm{~m}$ & $\mathrm{AB} 053512$ \\
\hline 22 & Op. rufocuprescens chormaensis & NW. China: Xinjiang, $100 \mathrm{~km}$ E. of Narat, $2500 \mathrm{~m}$ & AB053513 \\
\hline 23 & Lipaster stjernvalli ssp. & NE. Turkey: Col d'Ilgar, $2400 \mathrm{~m}$ & $\mathrm{AB} 053514$ \\
\hline 24 & Li. stjernvalli ssp. & NE. Turkey: Cham Yech, $2200 \mathrm{~m}$ & $\mathrm{AB} 053515$ \\
\hline 25 & Li. stjernvalli ssp. & SW. Georgia: Adzharia, 10km S. of Batumi, Tscharmali vil., $100 \mathrm{~m}$ & $\mathrm{AB} 053516$ \\
\hline 26 & Mimocarabus maurus hochhuthi & NE. Turkey: Giresun Mts., Gönderic Tepesi, $2000 \mathrm{~m}$ & $\mathrm{AB} 053517$ \\
\hline 27 & Mi. elbursensis & $\begin{array}{l}\text { N. Iran: Mazandaran, Alam-Kuh between Rudbarak \& Delir, } \\
2300 \mathrm{~m}\end{array}$ & AB053518 \\
\hline 28 & Morphocarabus estreicheri & $\begin{array}{l}\text { SW. Russia: } 200 \mathrm{~km} \mathrm{~N} \text {. of Rostov-na-Donu, Efremo-Stepanovla } \\
\text { env. }\end{array}$ & AB053519 \\
\hline 29 & Mo. sibiricus haeres & SW. Russia: Belgorod, near Borisovka steppe & AB053520 \\
\hline 30 & Mo. sibiricus obliteratus & E. Kazakhstan: Zyryanovsk env., Putintzevo vil., $600 \mathrm{~m}$ & $\mathrm{AB} 053521$ \\
\hline 31,32 & Mo. mandibularis bukhtarmensis & E. Kazakhstan: Kalbinskii Mts., Ognevka vil. env., $600 \mathrm{~m}$ & $\mathrm{AB} 053522$ \\
\hline 33,34 & Mo. scabriusculus & S. Slovakia: Zádiel env. & AB053523/АB053524 \\
\hline 35 & Mo. monilis scheidleri & W. Czech: S. Bohemia, Jindris env. (Jindr Hradec), $480 \mathrm{~m}$ & $\mathrm{AB} 053525$ \\
\hline 36,37 & Mo. rothi diffinis & NW. Romania: Judet Cluj, Pustuta env. & AB053526/АB053527 \\
\hline 38,39 & Mo. rothi hampei & CW. Romania: Judet Hunedoari, Scarimb env. & AB053528/AB053529 \\
\hline 40 & Mo. monilis kollari & SW. Romania: Judet Caras-Severin, Sasca Montana env. & AB053530 \\
\hline 41,42 & Mo. rothi ulrichhoffmanni & SW. Romania: Judet Caras-Severin, Borlova env. & $\mathrm{AB} 053531$ \\
\hline 43,44 & Mo. rothi comptus & SW. Romania: Judet Caras-Severin, Tincova env. & AB053531/AB053532 \\
\hline
\end{tabular}




\begin{tabular}{|c|c|c|c|}
\hline 45,46 & Mo. rothi hampei & NW. Romania: Judet Salaj, Aghires env. & AB053533/AB053534 \\
\hline 47 & Mo. henningi uralicus & SW. Russia: S. Ural, Iuriuzan, Mt. Iremel, $800 \mathrm{~m}$ & $\mathrm{AB} 053535$ \\
\hline 48 & Mo. henningi sahlbergi & S. Russia: Tuva, Akademika Obrucheva Mts., Koptu Riv. val., 900 m & AB053536 \\
\hline 49 & Mo. henningi & S. Russia: Krasnoyarski, Aradanski, Aradan & $\mathrm{AB} 053537$ \\
\hline 50 & Mo. regalis & E. Kazakhstan: Zyryanovsk env., Putintzevo vil., $600 \mathrm{~m}$ & AB053538 \\
\hline 51 & Mo. regalis jenissoni & S. Russia: Tuva, Akademika Obrucheva Mts., Koptu Riv. val., 900 m & AB053539 \\
\hline 52 & Mo. regalis & S. Russia: Krasnoyarski, Aradanski, Aradan & AB053540 \\
\hline 53 & Mo. henningi & S. Russia: Tuva, Mun Lake Bass, $850 \mathrm{~m}$ & $\mathrm{AB} 053541$ \\
\hline 54 & Mo. henningi & S. Russia: Tuva, Todzh, Azas Lake, $990 \mathrm{~m}$ & $\mathrm{AB} 053542$ \\
\hline 55 & Mo. odoratus septentrionalis & N. Russia: Polar Ural Mts., Sob Riv., St. Sob env., 300-500 m & $\mathrm{AB} 053543$ \\
\hline 56 & Mo. odoratus krugeri & S. Russia: Tuva, Akademika Obrucheva Mts., Sainak Pass, 2100 m & $\mathrm{AB} 053544$ \\
\hline 57 & Mo. chaudoiri zaikai & S. Russia: Tuva, Akademika Obrucheva Mts., Sainak Pass, 2100 m & $\mathrm{AB} 053545$ \\
\hline 58 & Mo. michailovi & E. Kazakhstan: S. Altai, Sarym-Sakty Mts., Sarym-Sakty Riv. & AB053546 \\
\hline 59 & Mo. spasskianus cracens & E. Kazakhstan: Kalbinskii Mts., Ognevka vil. env., $600 \mathrm{~m}$ & $\mathrm{AB} 053547$ \\
\hline 60 & Mo. eschscholtzi zyrianovskianus & E. Kazakhstan: Zyryanovsk env., Putintzevo vil., $600 \mathrm{~m}$ & AB053548 \\
\hline 61 & Mo. shestopalovi & E. Kazakhstan: S. Altai, Sarym-Sakty Mts., Sarym-Sakty Riv. & AB053549 \\
\hline 62 & Mo. aeruginosus & S. Russia: Tuva, Todzh, Azas Lake, $990 \mathrm{~m}$ & AB053550 \\
\hline 63 & Mo. aeruginosus herrmanni & SW. Russia: S. Ural, Iuriuzan, Mt. Iremel, $800 \mathrm{~m}$ & $\mathrm{AB} 053551$ \\
\hline 64 & Mo. aeruginosus & S. Russia: Krasnoyarski, Sayanogorsk dist., Cheremushki, $800 \mathrm{~m}$ & AB053552 \\
\hline 65 & Mo. aeruginosus & S. Russia: Tuva, Akademika Obrucheva Mts., Koptu Riv. val., 900 m & AB053553 \\
\hline 66 & Mo. subcostatus & S. Russia: Krasnoyarski, Aradanski, Aradan & $\mathrm{AB} 053554$ \\
\hline 67 & Mo. tarbagataicus & E. Kazakhstan: Saur Mts., Sargar Mt., $2200 \mathrm{~m}$ & $\mathrm{AB} 053555$ \\
\hline 68 & Mo. gebleri ultimus & E. Kazakhstan: Zyryanovsk env. & $\mathrm{AB} 053556$ \\
\hline 69 & Mo. venustus ssp. (aff. opacipennis) & N. Korea: Hamgyongnam-do, Huchi Lyong & $\mathrm{AB} 053557$ \\
\hline 70 & Mo. venustus liaoningensis & NE. China: Liaoning, Xinbin, Jiahe & AB053558 \\
\hline 71 & Mo. wulffiusi & NE. China: Heilongjiang, Hailin & AB053559 \\
\hline 72 & Mo. venustus liaoningensis & NE. China: Liaoning, Dandong, Mt. Shifang Ding & $\mathrm{AB} 050678$ \\
\hline 73 & Mo. venustus liaoningensis & NE. China: Liaoning, Kuandian & AB053560 \\
\hline 74,75 & Mo. venustus liaoningensis & NE. China: Liaoning, Fengcheng & $\mathrm{AB} 053560 / \mathrm{AB} 053561$ \\
\hline 76 & Mo. venustus odaesanus & S. Korea: Kangwon-do, Odae-san Mts. & $\mathrm{AB} 053562$ \\
\hline 77 & Mo. venustus odaesanus & S. Korea: Kyonggi-do, Mt. Ungil-san & AB053562 \\
\hline 78 & Mo. latreillei pyonganensis & N. Korea: Pyonganbuk-do, Pihyon, Mt. Paekma-san & AB053563 \\
\hline 79 & Mo. latreillei latreillei & E. Russia: Buryatia reg., Belozersk env. & AB053564 \\
\hline 80 & Mo. hummeli ssp. (aff. suensoni) & NE. China: Beijing, Xiaolongmen & AB053565 \\
\hline 81 & Mo. hummeli tristiculus & NE. China: Heilongjiang, Hailin & AB053566 \\
\hline 82 & Mo. hummeli smaragdulus & E. Russia: Amur, Vysokogornyi & AB050679 \\
\hline 83 & Mo. hummeli nevelskii & E. Russia: N. Sakhalin, Usukovo & $\mathrm{AB} 053567$ \\
\hline 84 & Rhigoidocarabus zhubajie & C. China: Shaanxi, Qinling Mts., Mt. Taibai Shan, $2500 \mathrm{~m}$ & AB053568 \\
\hline 85 & Rh. zhubajie & C. China: Shaanxi, Qinling Mts., Mt. Taibai Shan, $2000 \mathrm{~m}$ & AB053568 \\
\hline$* *$ & Archicarabus monticola & NW. Italy: Piemonte, Cúneo, Brondello & AB047259 \\
\hline$* *$ & Ar. nemoralis & N. Germany: Niedersachsen, Hildesheim, Lamspringe & AB047265 \\
\hline
\end{tabular}

\footnotetext{
* The specimen numbers correspond to those in the phylogenetic trees.

** Taken as an outgroup for constructing the trees in Fig. 2.
}

and the localities where the samples were collected are listed in Table 1 and in Fig. l, respectively. The specific names adopted by Imura and Mizusawa (1996) were used throughout.

The specimens were stored in $95 \%$ ethanol until dissection. Total DNA was extracted from thorax muscle $(10-25 \mathrm{mg})$ of a single adult individual using QIA Amp DNA Mini kit (QIAGEN). The total DNA was used as a template for amplification of ND5 DNA fragment by the polymerase chain reaction (PCR) (Saiki et al., 1988). The 


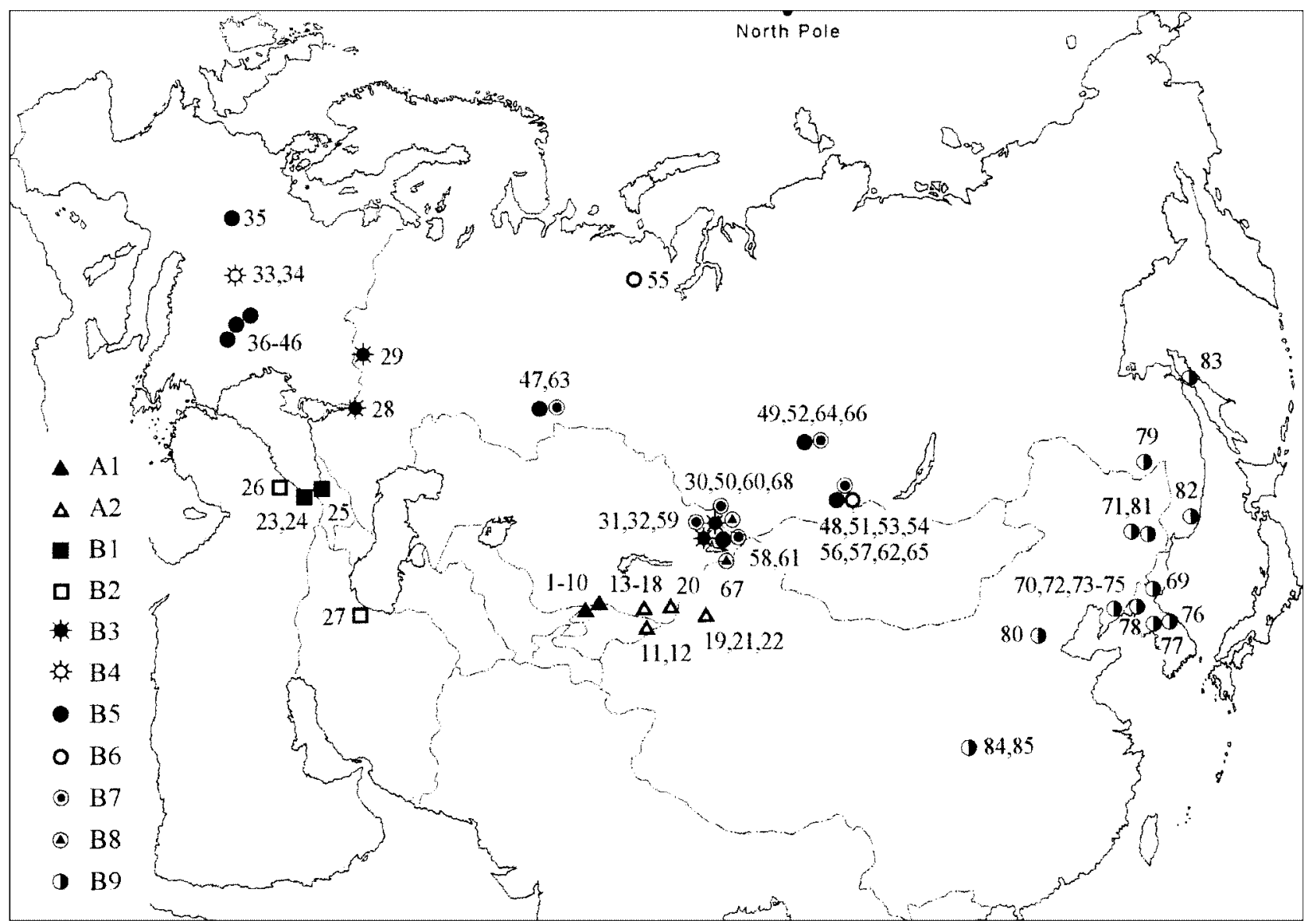

Fig. 1. Locality map of the specimens used in this study. Numbers correspond to those in Table 1 and Fig. 2.

1,084-bp sequence which contains a 1,069-bp 3 ' region of the ND5 gene, 8- bp of noncoding sequence, and a 7- bp 5 ' terminus of the Phe-tRNA gene was amplified by the V1.04 primer (5'-GTC ATA CTC TAA ATA TAA GCT A3') and the Vl.06 primer (5'-CCT GTT TCT GCT TTA GTT CA-3') (Su et al., 1996). PCR amplifications were carried out in a $50 \mu \mathrm{l}$ mixture containing $5 \mu \mathrm{l}$ of 10X Ex Taq Buffer (TaKaRa), $0.2 \mathrm{mM}$ of each dNTP, $0.5 \mu \mathrm{M}$ of each primer, and $2.5 \mathrm{U}$ of Taq polymerase (TaKaRa EX Taq, TaKaRa). PCR was performed for 35 cycles of denaturation at $94^{\circ} \mathrm{C}$ for $1 \mathrm{~min}$., primer annealing at $50^{\circ} \mathrm{C}$ for 1 min., and extension at $70^{\circ} \mathrm{C}$ for 2 min. using a GenAmp PCR system 9700 (Perkin Elmer). The final single cycle was done under the same conditions but with an extension step at $70^{\circ} \mathrm{C}$ for $7 \mathrm{~min}$. The PCR product was purified with QIA quick PCR purification kit (QIAGEN) (Su et al., 1998).

Direct sequencing was performed with an automated ABI PRISM 377 DNA sequencer using the dideoxy chain termination method (Sanger et al., 1977). The reaction mixture for cycle sequencing consisted of $6 \mu \mathrm{l}$ of dRhodamine terminator cycle sequencing ready reaction with AmpliTaq DNA polymerase, FS (Applied Biosys- tems), $0.1-0.3 \mathrm{pmol}$ of DNA, $2.4 \mu \mathrm{l}(1 \mathrm{pmol} / \mu \mathrm{l})$ of sequencing primer, and $\mathrm{H}_{2} \mathrm{O}$ to a total volume of $15 \mu \mathrm{l}$. The cyclesequencing conditions were 25 cycles at $96^{\circ} \mathrm{C}$ for $10 \mathrm{sec}$, $50^{\circ} \mathrm{C}$ for $5 \mathrm{sec}$, and $60^{\circ} \mathrm{C}$ for $4 \mathrm{~min}$., followed by an indefinite hold at $4^{\circ} \mathrm{C}$ using a GeneAmp PCR system 9700 (Perkin Elmer). The DNA product was cleaned with Centri-Sep spin column (Applied Biosystems) and vacuum-dried before applying. Mostly, two primers used for PCR were sufficient to read 1,084 bp sequence. In some cases, two internal primers were used : forward primers Ezo-2, and reserve primers AO-3 (Su et al., 1998).

The ND5 gene sequences were aligned and compared using the multiple-alignment program CLUSTAL W, version 1.5 (Thompson et al., 1994). The phylogenetic trees were constructed by four methods; the unweighted pair grouping method with arithmetic means (UPGMA), the neighbor-joining (NJ) (Saitou and Nei, 1987), maximum parsimony (MP) and maximum likelihood (ML) methods. The DNA sequence analysis package SINKA, version 3.0 (Fujitsu System Engineering, Japan) was used to construct the NJ- and UPGMA-trees with the evolutionary distance (D) computed by Kimura's two-parameter method (Kimura, 1980), and the trees were tested by 
500 bootstrap resamplings (Felsenstein, 1985). The MP and ML analyses were performed by DNAPARS, DNAML, SEQBOOT and CONSENSE programs of PHYLIP (Phylogeny Inference Package) software package, version 3.5c (Felsenstein, 1993).

The evolutionary distances between geographically isolated races of three carabid species in conjunction with geohistorical data showed that chronology by the ND5 gene and that by geology agree well ( $\mathrm{Su}$ et al., 2001). Based on this finding, the dating was done assuming that a $0.01 \mathrm{D}$ unit corresponds to 3.6 million years for nearly the constant substitution rate of the ND5 gene (Su et al., 2001).

\section{RESULTS AND DISCUSSION}

The ND5 gene sequences did not require deletions/ insertions for multiple alignment. The $\mathrm{G}+\mathrm{C}$ contents were nearly constant $(21 \pm 1.0 \%)$. Most substitutions were found at the codon silent positions. Multiple substitutions were corrected by Kimura's formula (Kimura, 1980). This together with very little difference in $G+C$ content of the gene, suggests the lack of appreciable effects of base composition bias and multiple substitutions on the phylogenetic trees.

Molecular phylogeny based on the ND5 gene sequences To see reliability of a phylogeny by the ND5 gene, genealogical trees were constructed by means of the UPGMA, neighbor joining (NJ), maximum parsimony (MP) and maximum likelihood (ML) methods for all the samples treated in this paper. As shown in Fig. 2, all these trees yielded essentially the same topology with some minor differences between the ML-tree and the other three trees (see below), which did not seriously affect the discussion in this paper.

The above comparative study may be taken to justify that any one of the methods can be used to reconstruct a reliable phylogeny of the division Lipastromorphi.

From these trees, it is reasonable to recognize two major lineages, $\mathrm{A}$ and $\mathrm{B}$, which are respectively divided into two sublineages (A1 and A2), and nine sublineages (B1 to B9). B5 and B9 are further separated each into two (B5a and B5b) and three (B9a to B9c) clusters (Fig. 2). The separation of the lineages $A$ and $B$ was estimated to have occurred about 35 million years ago (MYA) as calculated according to Su et al. (2001).

Lineage A. Two sublineages, A1 and A2, which include the Cyclocarabus species, and the Ophiocarabus plus Cryptocarabus species, respectively, were separated long ago. All these species inhabit the Tianshan Mountains of Central Asia.

Sublineage A1 (Cyclocarabus). Diagnosis: 12-32 mm in length. Black and rather polished, with head rather hypertrophic, and elytral sculpture much degenerated; endophallus with paraligula very large and strongly bent right laterally, both median lobe and praeputial pad triangularly protruded, pigmented spot present, lacinia also present though very short, aggonoporius not strongly sclerotized. In Fig. 3, the sketch of the endophallus is shown to help understanding the morphological characters of male genital organ of the Lipastromorphi species. Fig. 4 shows the photographs of the male genital organ and the habitus of the representative species in each sublineage.

A1 contains five morphological species (namanganensis, martynovi, pseudolamprostus, karaterekensis and minusculus), and yet their sequences are so close that they are hardly distinguishable from one another. They are similar in the external appearance, although treated as five different species mainly based on somewhat differently shaped aedeagal apex. In view of both the molecular and morphological evidence, taxonomic treatment of these Cyclocarabus "species" should be reconsidered.

Sublineage A2 (Ophiocarabus + Cryptocarabus). Diagnosis: $14-23 \mathrm{~mm}$ in length. Endophallic structure of male genitalia is similar between these two (sub)genera, with morphology of lacinia somewhat variable among the species (see Fig. 4: Nos. 2-4). Discrimination between the two (sub)genera seems to be possible only by superficial characters such as body color, etc. Upper surface of the Ophiocarabus species usually bears a metallic tint, legs are more or less reddish, and body is slenderer, while in the Cryptocarabus species, upper surface is usually blackish and mat, legs also blackish and body is rather robuster.

The branching points among various A2 species are relatively deep as compared with those in A1. The Ophiocarabus species in A2 appear in two distinctly separate clusters in the UPGMA-, NJ- and MP-trees, and two Cryptocarabus species are intermingled with Ophiocarabus in one of the clusters in A2, while on the ML-tree they fall out in a single cluster with exclusion of Ophiocarabus. In any sense, these two (sub)genera are phylogenetically closely related to each other in accordance with the previously published morphological evidence. The sequence divergence of four Cryptocarabus species examined (kadyrbekovi, sacarum, lindemanni and subparallelus) is small. The sequence of lindemanni is identical with that of subparallelus from the nearby localities (northwestern foot of the Zailiiskii Alatau and the Kok-Tinbe Mountains near Almaty).

The molecular phylogeny of the lineage A generally agrees with the traditional taxonomy at the supraspecific level, but the separation of Ophiocarabus from Cryptocarabus is somewhat ambiguous (see above). The taxonomy at the species level is not consistent with the present molecular phylogeny, presumably because morphological differences of these species have not much value to discriminate them as the species. 
(a)

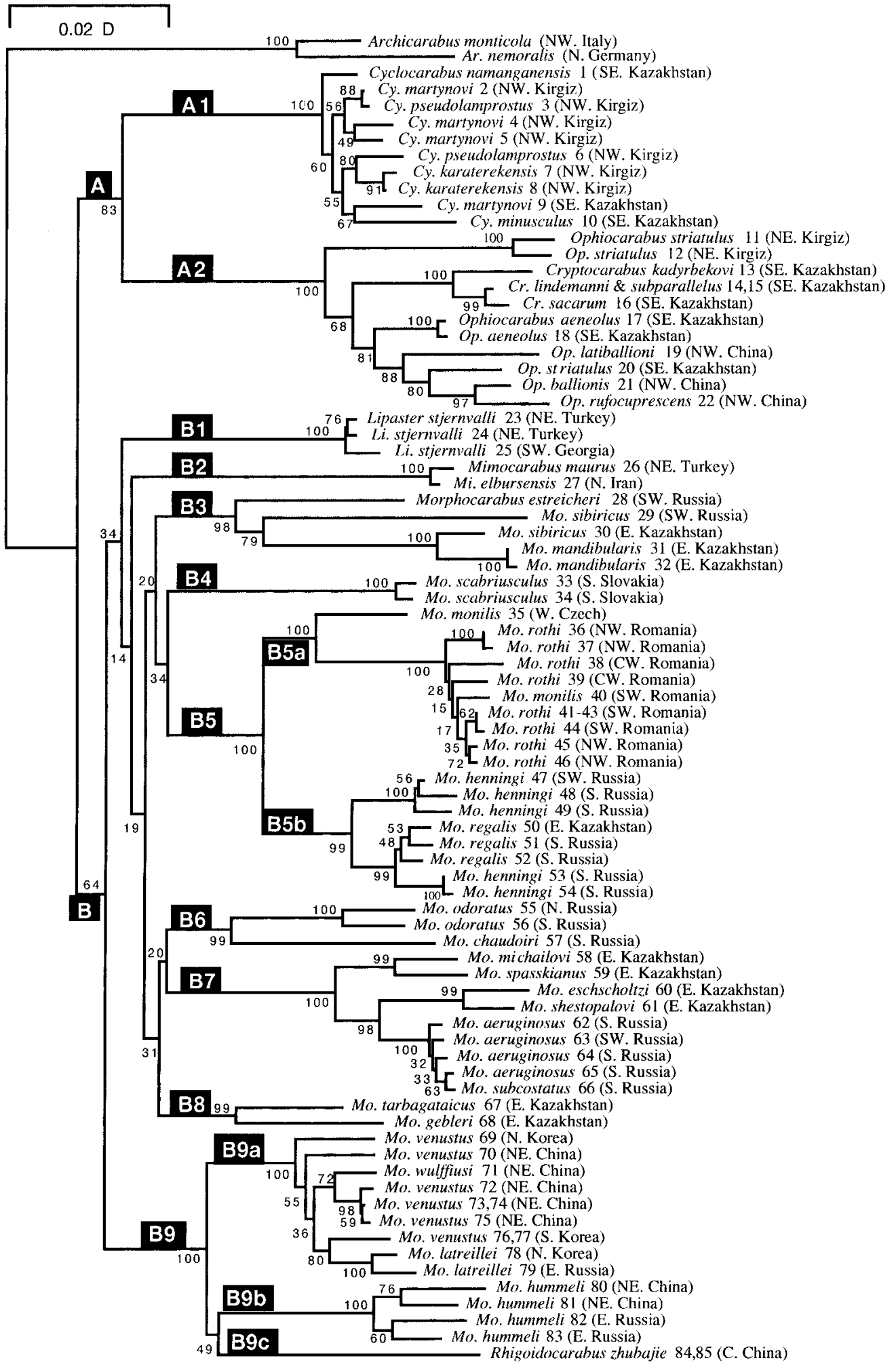


(b)

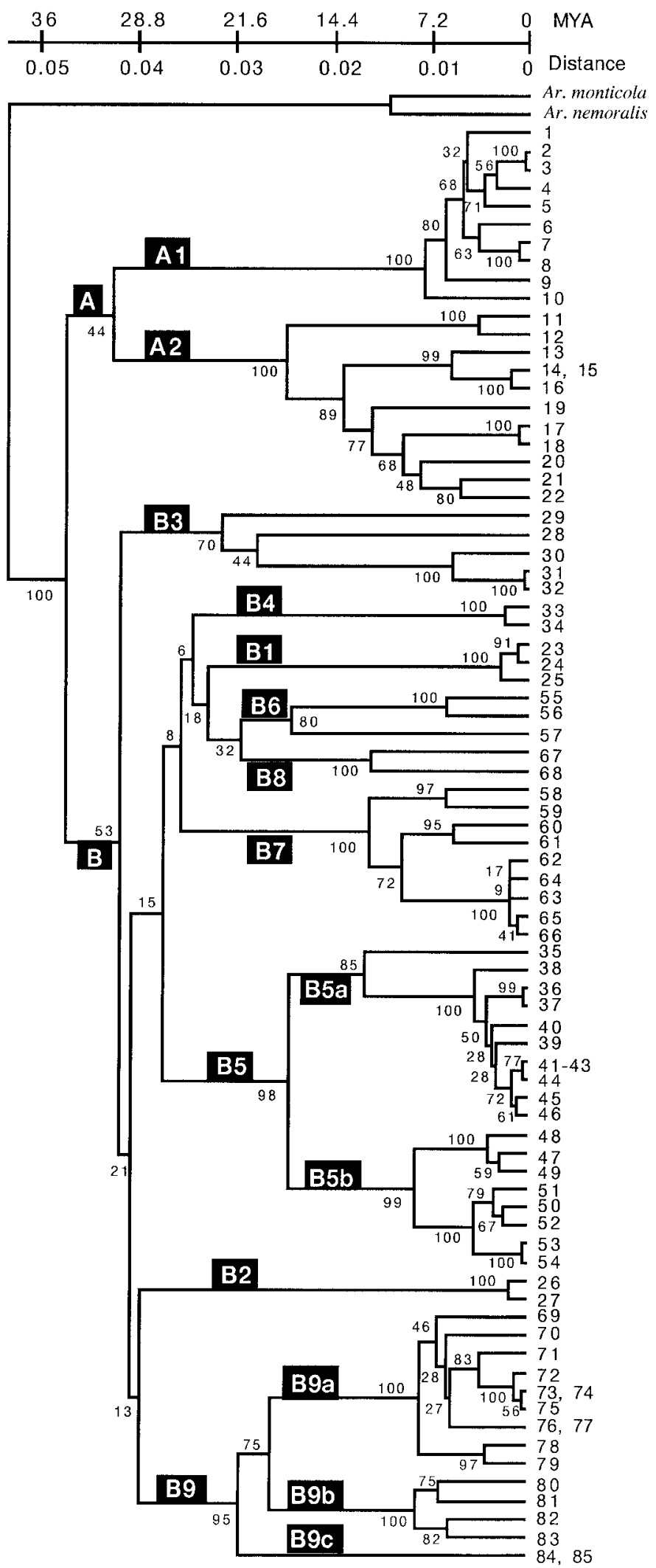




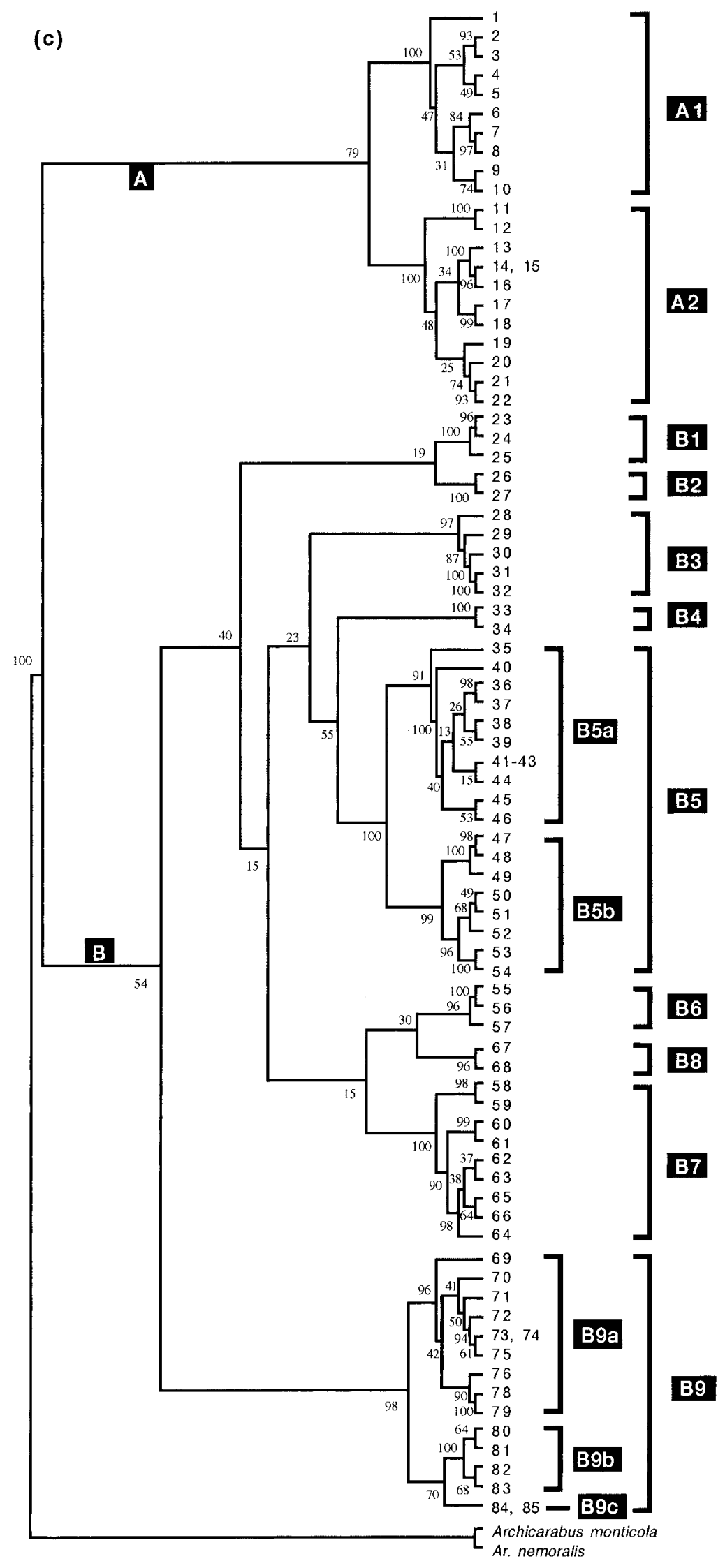


(d)
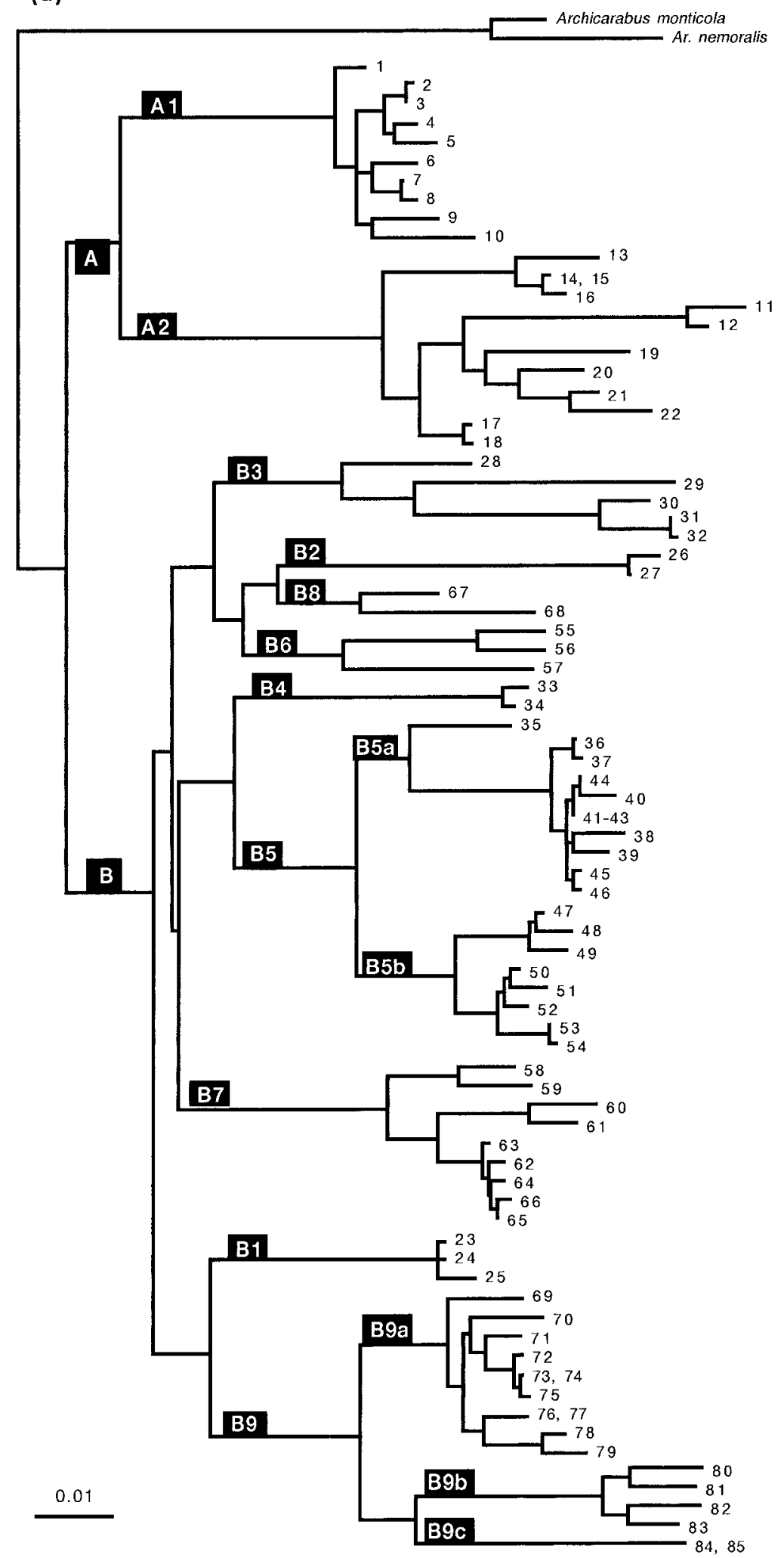

Fig. 2. NJ- (a), UPGMA- (b), MP- (c) and ML- (d) trees of the mitochondrial ND5 gene of the division Lipastromorphi. The number in each branching point indicates the bootstrap percentage for $a, b$ and $c$. The (sub)lineage names are shown in each tree. The tree was outgroup-rooted using the ND5 gene of Archicarabus monticola and Ar. nemoralis (division Archicarabomorphi; for molecular phylogeny, see Imura et al., 2000). Only the specimen numbers corresponding to those in Fig. 2a are shown in the UPGMA-, MP- and ML-trees. 


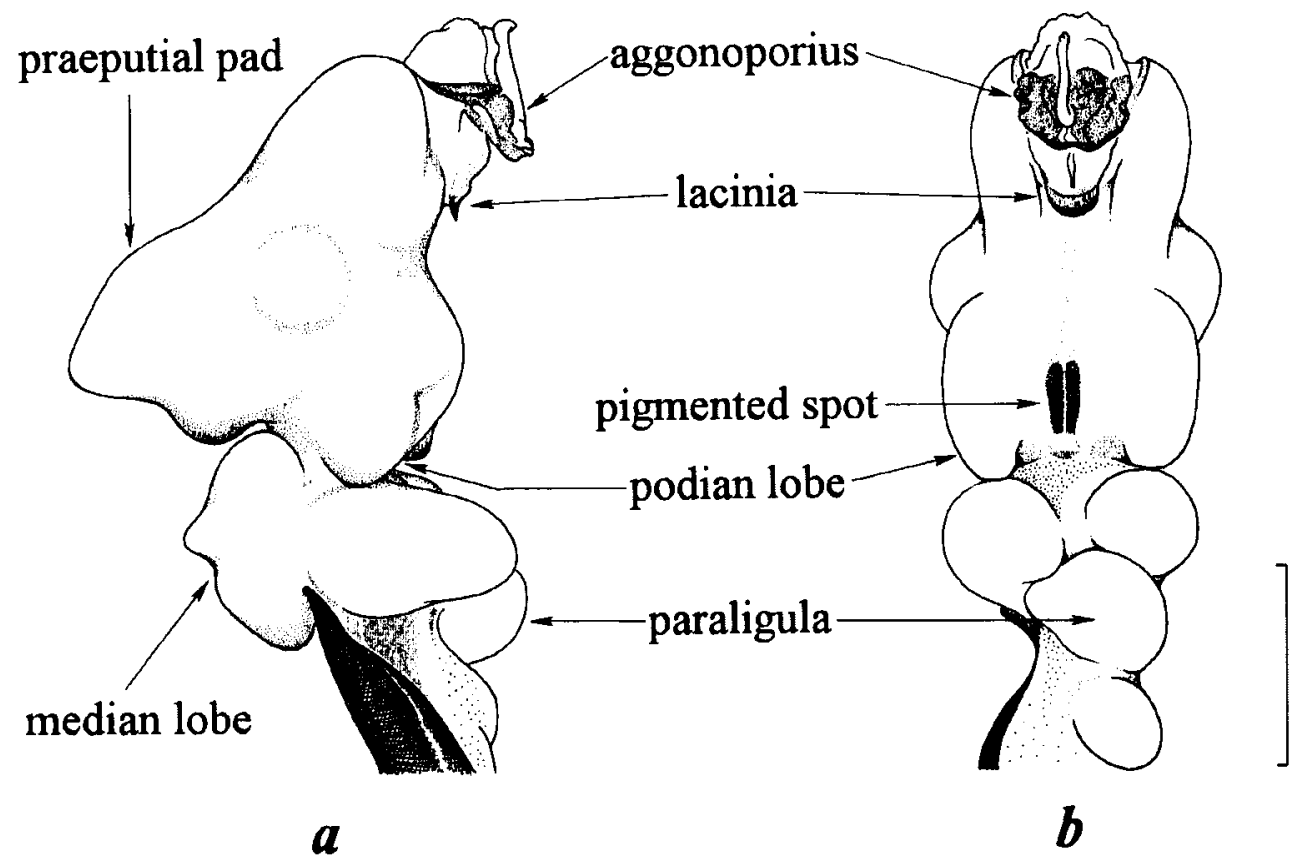

Fig. 3. Morphology of male genital organ of the Lipastromorphi beetles. The sketched illustration for the male genital organ of Morphocarabus monilis scheidleri (see Fig. 4: No. 10) is shown to help understanding the morphological characters of male genital organ. Fully everted endophallus in right lateral view (a) and basal view (b). Scale: $2 \mathrm{~mm}$.

Lineage B. The lineage B contains the species of Lipaster, Mimocarabus, Morphocarabus and Rhigoidocarabus, and is, as mentioned above, separated into 9 sublineages, B1 to B9. Their branching order can not be estimated because of the short branch lengths supporting the respective lineages and low bootstrap values in the NJ-, MP- and UPGMA-trees. This suggests that these groups radiated within a short time.

Sublineage B1 (Lipaster). Diagnosis: $19-45 \mathrm{~mm}$ in length. Upper surface usually bears strong metallic luster or sometimes mat blackish; head strongly hypertrophic with front margin of labrum deeply emarginate, outer margin of mandible convexly protruded before deep emargination near base; elytral sculpture much degenerated; paraligula large and strongly bent right laterally, median lobe conspicuously inflated, a pair of hairy areas present on ventral wall of endophallus, pigmented spot large and strongly sclerotized, lacinia faintly recognized, aggonoporius weakly sclerotized (see Fig. 4: No. 5).

B1 is composed of a sole species Lipaster stjernvalli from Northeast Turkey and Southwest Georgia. The sequences of the three specimens examined are almost the same.

Sublineage B2 (Mimocarabus). Diagnosis: 15-27 mm in length. Upper surface black or sometimes partly reddish; head slightly hypertrophic; shoulders distinct; elytral sculpture rather degenerated or at most scabrous; paraligula large and strongly bent right laterally, praeputial pad conspicuously prominent, pigmented spot long, narrow and well-sclerotized, lacinia strongly sclerotized and pigmented, aggonoporius sclerotized (see Fig. 4: No. $6)$.

B2 is represented by two species of Mimocarabus, maurus from Northeast Turkey and elbursensis from North Iran. They have been discriminated from one another mainly by somewhat different elytral sculpture and aedeagal apex, and yet they have almost the same ND5 gene sequence.

Classification of Mimocarabus and Lipaster as two independent (sub)genera (Brezina, 1999; Imura and Mizusawa, 1996) is consistent with the present molecular phylogeny, in which B1 (Lipaster) and B2 (Mimocarabus) are clearly separated from each other.

Sublineages B3-B9 (Morphocarabus s. lat. + Rhigoidocarabus). Diagnosis: $14-40 \mathrm{~mm}$ in length. Head usually not so hypertrophic; coloration of upper surface, elytral sculpture and endophallic structures variable according to taxa, and thus sublineage-specific characters hardly defined (see Fig. 4: Nos. 7-20).

B3 consists of three dark colored Morphocarabus species, estreicheri (Southwest Russia) (Fig. 4: No. 7), sibiricus (Southwest Russia and East Kazakhstan) and mandibularis (East Kazakhstan) (Fig. 4: No. 8). This sublineage may be divided into three lines that were separated long ago. Note that sibiricus haeres from Southwest Russia is quite remote from another subspecies, $s$. obliteratus, from East Kazakhstan which is clustered with a Kazakh species, mandibularis. Indeed, the external appearance of $s$. haeres is rather distinct from that of the other subspecies. Thus, the phylogeny of the species 
and subspecies is geographically linked and does not exactly reflect their taxonomy. The molecular phylogeny shows that all the species in B3 are only remotely related to other Morphocarabus species (B4 to B9) to be enumerated below.

B4 consists of a single species, Morphocarabus scabriusculus (Fig. 4: No. 9), from South Slovakia.

The specimens in B5 consist of four Morphocarabus species that are separated into two major clusters, B5a and B5b. B5a contains two species, monilis (Fig. 4: No. 10) and rothi from South Bohemia and several parts of West Romania. Since one specimen (No. 40) of Mo. monilis is intermingled in the Mo. rothi cluster with only very small sequence differences, it is possible that the no. 40 monilis could be the result of introgression of the Mo. rothi mitochondria. Alternatively, these two species may be the same "phylogenetic" species, or at most conspecific, because monilis and rothi are morphologically close. B5b consists of henningi (Fig. 4: No. 11) and ragalis (Fig. 4: No. 12) from South Ural and South Siberia. These two species are readily discriminated from each other by differently shaped endophallus (see Figs. 14 bc \& $15 \mathrm{~b}-\mathrm{c})$. From the tree, it is likely that Mo. regalis was derived from Mo. henningi, because they seem to have branched off from one of the two Mo. henningi clusters.

B6 includes two rather distantly related Morphocarabus species, chaudoiri (South Siberia) and odoratus (Polar Ural and South Siberia) (Fig. 4: No. 13).

B7 contains five species of Morphocarabus from South Ural and South Siberia, and is divided into three wellseparated groups. The first group contains two species, michailovi and spasskianus, both from East Kazakhstan, which are separated from each other. The second group contains two Kazakh species, eschscholtzi and shestopalovi. The third one consists of two allied species, aeruginosus (Fig. 4: No. 14) and subcostatus (which is often synonymized with aeruginosus), from South Ural and South Siberia, and the evolutionary distance among all the specimens examined is almost null.

B8 contains two Morphocarabus species, tarbagataicus (Fig. 4: No. 15) and gebleri (Fig. 4: No. 16), both from the easternmost part of Kazakhstan. Although the branching point of these two species is rather deep, they form a single cluster. This is consistent with a similarity of the endophallic structures of these two species (Fig. 4: Nos. $15 \mathrm{~b}-\mathrm{c}$ and $16 \mathrm{~b}-\mathrm{c}$ ) as noted by Obydov (1999).

B9 is further divided into three clusters, B9a, B9b and B9c that radiated fairly long ago. B9a includes three Morphocarabus species, venustus (Fig. 4: No. 17), wulffiusi and latreillei (Fig. 4: No. 18), from Northeast China, Korea and Amur. B9b is composed solely of hummeli (Fig. 4: No. 19) from Northeast China, Amur and Sakhalin. In both B9a and B9b, diversification started relatively recently. Venustus, wulffiusi and latreillei are intermingled in B9a without forming the species-specific cluster in all the trees, suggesting that the phylogeny does not necessarily reflect their taxonomy. Note that venustus and wulffiusi have often been treated as the same species. B9c is composed of a single species, "Carabus" zhubajie (Fig. 4: No. 20), from Shaanxi of Central China. This species was originally described as a member of the subgenus Rhigocarabus in the division Latitarsi (Imura, 1993). Later, Deuve (1997) placed it in the Lipastromorphi, with proposal of a new subgenus, Rhigoidocarabus. The present result is consistent with the Deuve's view. As shown in Fig. 4 (No. 20b), praeputial pad of zhubajie is extraordinarily inflated, and yet its basic structure as well as other morphological characters is in a range of the Morphocarabus groups with an affinity to B9a and B9b.

Pattern of diversification $\mathrm{Su}$ et al. (2001) pointed out that the major carabine divisions explosively radiated 50-40 MYA, followed by occasional radiations with various scales. The Lipastromorphi ground beetles belong to one of the divisions emerged at the time of this radiation. Its diversification probably started about 35 MYA with separation of the lineages A and B, followed by radiation of various sublineages included therein within a relatively short time. Thus, the evolutionary histories of each lineage and sublineage are old, corresponding to $4 / 5-1 / 2$ of the history of the Carabina evolution.

As shown in Fig. 5, the distribution range of each lineage and sublineage is more or less geographically linked. Although some of them such as A1, A2, B1, B8 and B9c inhabit a narrowly restricted area without overlap, some others such as B2, B4 and B5a occupy a moderately wide distribution area, and still some others such as B3, B5b, B6, B7 and B9a, b inhabit a greater part of the Eurasian Continent. As a result, partial or overall overlapping of distribution range is recognized between B3, B5b, B6, B7 and B9a, b, between B3, B4 and B5a and between $\mathrm{B} 1$ and $\mathrm{B} 2$.

A1 and A2 are strictly endemic to the Tianshans and the nearby regions and appear parapatrically. B1 and B2 are composed of the species from Northeast Turkey to Caucasus, and the species from Asia Minor to North Iran, respectively. Morphocarabus sibiricus in B3, among others, has the widest distribution range from North Ukraine to centro-eastern Siberia where two other species, estreicheri and mandibularis inhabit. B4 is composed of a single species, scabriusculus, which is distributed mainly in East Europe. B5a, including several races of monilis and rothi from West Czech and West Romania, occupy almost entire region of Central Europe, Great Britain and eastern part of Ireland. The species in B5b, B6 and B7 occupy wide areas in Central and East Eurasia, and their habitats are overlapped in centrosouthern Siberia. The distribution range of B8 is nar- 
rowly restricted to the easternmost part of Kazakhstan with a partial penetration into the Russian territory. B9 is rather widely distributed in the easternmost part of the Eurasian Continent including Sakhalin. B9c, to which only Rhigoidocarabus zhubajie belongs, inhabits a quite restricted area in Central China.

From the phylogeny and the distribution profile, it is hard to trace the origin and the distribution route of the Lipastromorphi species. After split of the lineages A and $\mathrm{B}$, the proto-type of A may have kept its distributional range around the Tianshans, while the proto-B expanded its distribution to almost entire region of the Eurasian Continent. The expansion accompanied geographical and/or reproductive isolation to form the phylogenetically isolated groups (sublineages, individual species, etc.). Occupation of the wide distribution ranges for some B2 sublineages might have been resulted rom the secondary expansion that occurred after the initial isolation. Thus, it is not unlikely, although by no means certain, that the ancestor of the Lipastromorphi would fhave emerged in
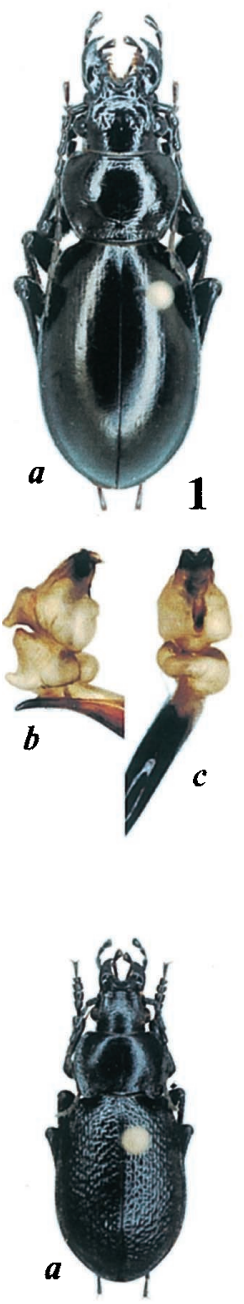

6

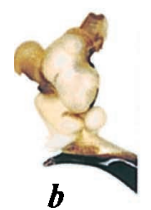

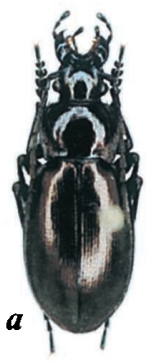

2
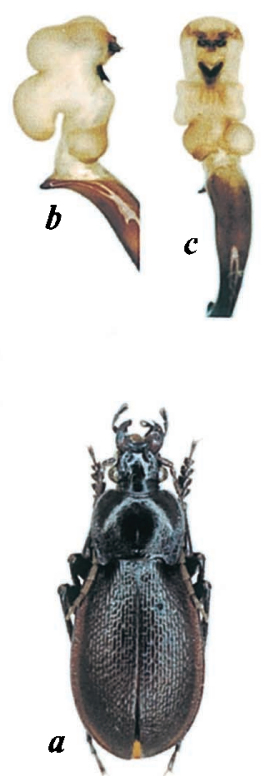

7

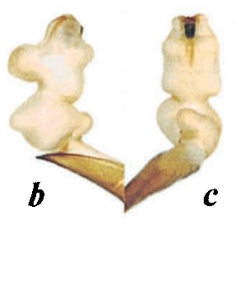

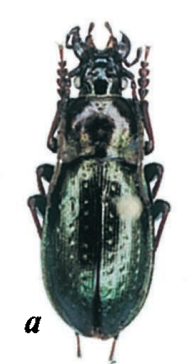

3
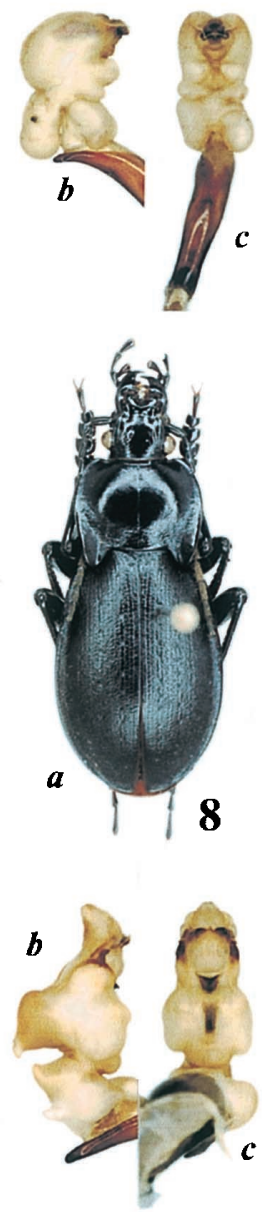

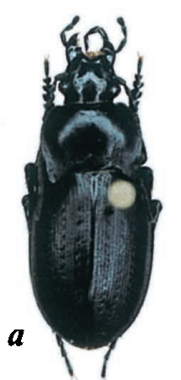

4
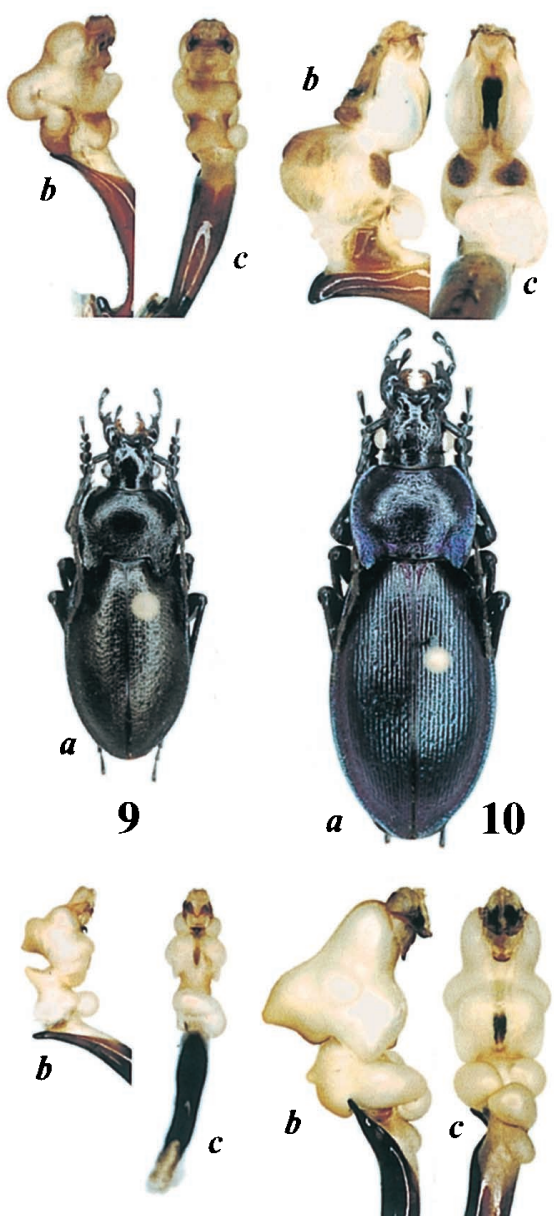

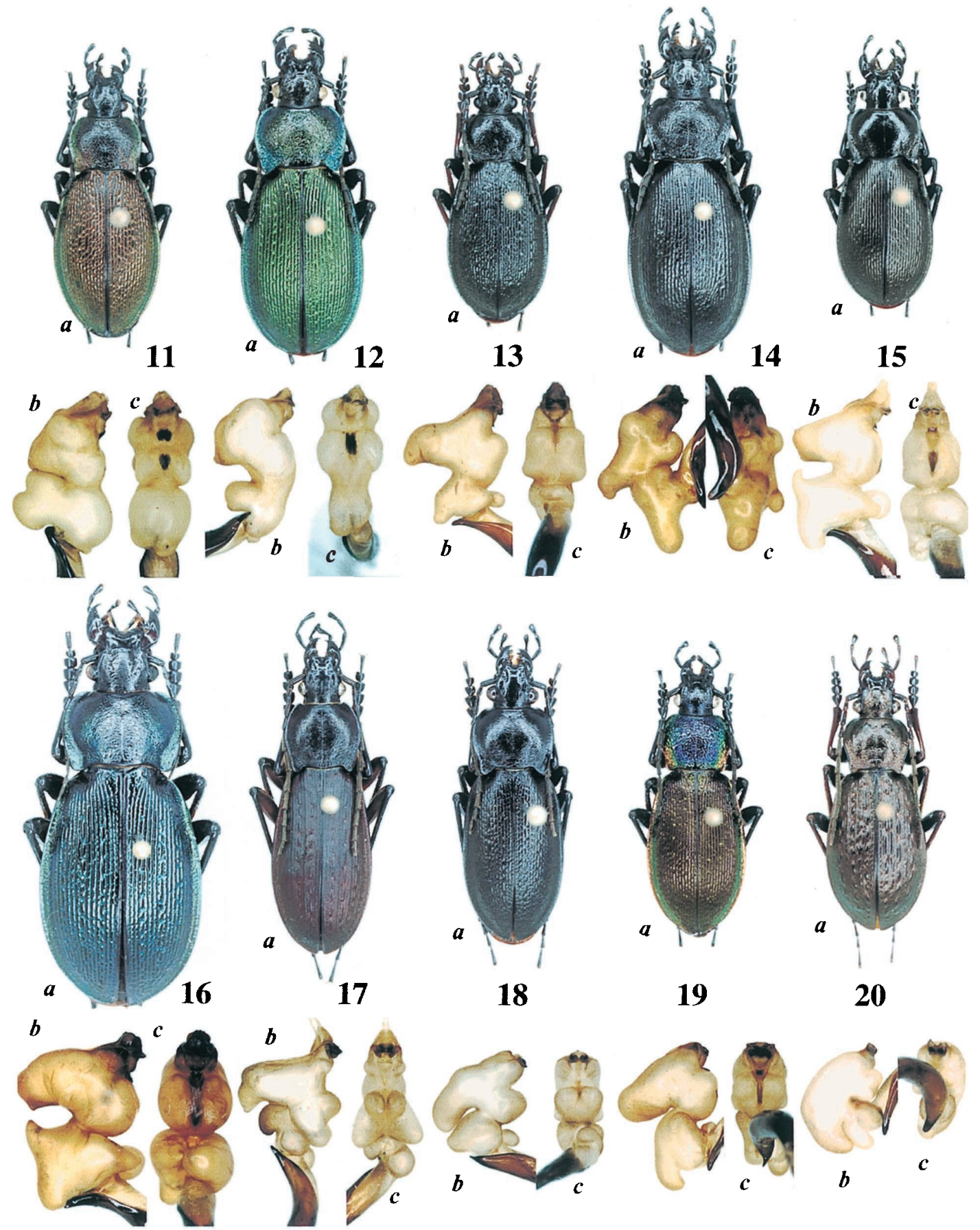

Figs. 4. Representative species of the Lipastromorphi. Habitus (a), male genital organ in right lateral view (b) and in basal view (c). The white spot on right elytron is a head of insect pin.

1, Cyclocarabus pseudolamprostus (locality: Pskem Mts., NW. Kirgiz; sublineage A1); 2, Ophiocarabus striatulus (Ketmen Mts., SE. Kazakhstan; A2); 3, Op. aeneolus (Transili Alatau Mts., SE. Kazakhstan; A2); 4, Cryptocarabus subparallelus (Zailiiskii Alatau Mts., SE. Kazakhstan; A2); 5, Lipaster stjernvalli (Kars, NE. Turkey; B1); 6, Mimocarabus maurus hochhuthi (Giresun, NE. Turkey; B2); 7, Morphocarabus estreicheri (Ul'iyanovsk, SW. Russia; B3); 8, Mo. madibularis buchtarmensis (S. Altaiskii Mts., E. Kazakhstan; B3); 9, Mo. scabriusculus (Zadiel, S. Slovakia; B4); 10, Mo. monilis scheidleri (Jindris, W. Czech; B5a); 11, Mo. henningi (Todzh, Tuva, S. Russia; B5b); 12, Mo. regalis (Zyryanovsk, E. Kazakhstan; B5b); 13, Mo. odoratus krugeri (Akademika Obrucheva Mts., Tuva, S. Russia; B6); 14, Mo. aeruginosus herrmanni (S. Ural, SW. Russia; B7); 15, Mo. tarbagataicus (Saur Mts., E. Kazakhstan; B8); 16, Mo. gebleri ultimus (Zyryanovsk, E. Kazakhstan; B8); 17, Mo. venustus liaoningensis (Fengcheng, Liaoning, NE. China; B9a); 18, Mo. latreillei (Archara, Amur, E. Russia; B9a); 19, Mo. hummeli smaragdulus (Gornyi, Amur, E. Russia; B9b); 20, Rhigoidocarabus zhubajie (Qinling Mts., Shaanxi, C. China; B9c). 


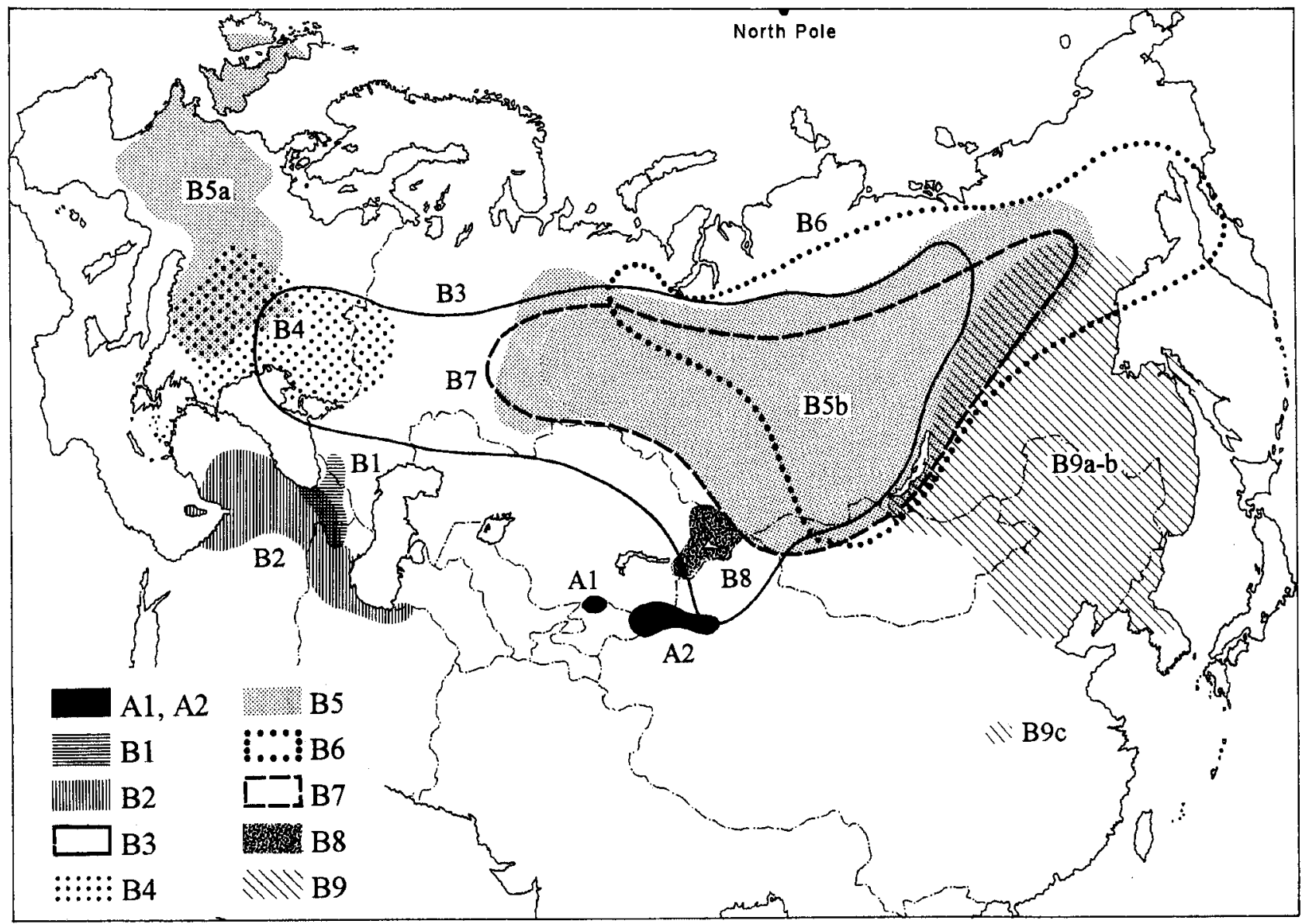

Fig. 5. Distributional ranges of the (sub)lineages. Each range covers the known localities in literatures (after Breuning, 1937 and Battoni et al., 1995). Some species and a considerable number of subspecies have been unable to examine in this study.

Central Asia, above all in the Tianshans and the nearby regions.

During the Lipastromorphi diversification, conspicuous morphological differentiation must have taken place upon or after split of the lineage $\mathrm{A}$ and the lineage $\mathrm{B}$, and emergences of sublineages $\mathrm{Al}, \mathrm{A} 2, \mathrm{~B} 1, \mathrm{~B} 2$ and $\mathrm{B} 3-\mathrm{B} 9$, as may be recognized by morphological difference on a generic level. Contrary to this, difference of the morphological characters among B3 through B9 groups is within the range of the species-difference so as to be not enough to differentiate the genera. In other words, the existence of the definite phylogenetic sublineages, B3 to B9, can only be recognized by the molecular phylogeny and not by morphology. Thus, the members of these sublineages have not undergone much morphological differentiation despite their long evolutionary histories.

From these observations, it may be inferred that the morphological evolution of the Lipastromorphi is largely "silent", with occasional occurrence of conspicuous morphological changes. Such a pattern is common in other carabid divisions (Su et al., 2001).
Taxonomic notes Taxonomy of Morphocarabus and its allied groups had been confused until Ishikawa (1978, 1979) assembled these superficially diversified groups into a single genus Lipaster which may be characterized by "the presence of a conspicuous inflation of the membranous walls at the dorsal base" of endophallus of male genitalia. Ishikawa $(1978,1979)$ divided Lipaster into eleven subgenera. However, the morphological characters he used to support these subgenera do not reflect the phylogenetic groups in the present study. The Lipastromorphi is one of the divisional names proposed by Deuve (1991), and is almost equivalent to the genus Lipaster in the Ishikawa's sense.

According to Imura (1996), the Lipastromorphi are classified into six subgenera as mentioned in introduction. Based on the ND5 gene trees, this division can be divided into two major lineages A and B. Two sublineages $\mathrm{A} 1$ and $\mathrm{A} 2$ in the lineage $\mathrm{A}$ and two sublineages B1 and B2 in the lineage B are well-defined by morphological characters and the traditional (sub)generic names can be adopted to each sublineage without conflict. The remaining seven sublineages B3 to B9 in 
the lineage B (= Morphocarabus $\mathrm{s}$. lat. plus Rhigoidocarabus zhubajie) that are present in the ND5 phylogeny can not be distinguished from each other by morphological characters but are definable as the discrete phylogenetic lines. These may be called the "phylogenetic (sub) genera".

We thank the following colleagues for supplying the invaluable specimens from various localities of the Eurasian Continent. Without their cooperation, this work could not have been accomplished. C. Auvray (Saint Sulpice, France), I. A. Belousov (St. Petersburg, Russia), B. Březina (Prague, Czech), M. L. Danilevsky (Moscow, Russia), W. Heinz (Schwanfeld, Germany), I. I. Kabak (Almaty, Kazakhstan), J. Kaláb (Jinacovice, Czech), M. Kawata (Sapporo, Japan), J.-K. Lee (Dandong, China), S. Murzin (Moscow, Russia), Y. Nagahata (Yamagata, Japan), D. Obydov (Moscow, Russia), P. A. Oudovichenko (Moscow, Russia), A. Plutenko (Smolensk, Russia), M. Tryzna (Decin, Czech) and H.-Z. Zhou (Beijing, China). Thanks are also due to Hideko Kanda (formally Tanaka) for skillful technical assistance. This work was supported in part by Grant-in-Aid for Scientific Research (B) (no. 13575013) from Japan Society for the Promotion of Science.

\section{References Cited}

Battoni, S., Casale, A., Cavazzuti, P., and Ratti, P. (1995) Les Coléoptères du monde, vol.8, Carabini 3: MorphocarabusLipaster. 104 pp., 25 pls. Sciences Nat, France.

Breuning, S. (1932-1937) Monographie der Gattung Carabus L. Best. -Tab. eur. Coleopt., (104-110): 1-1610, 41 pls. Reitter, Troppau.

Březina, B. (1999) World Catalogue of the Genus Carabus L. 170 pp. Pensoft, Sofia.

Deuve, Th. (1991) La nomenclature taxonomique du genre Carabus. Bibliothèque Entomologique, 4: 1-179, 60 figs. Science Nat, France.

Deuve, Th. (1997) Catalogue des Carabini et Cychrini de Chine. Mém. Soc. ent. Fr. (1): 1-236, 236 figs.

Felsenstein, J. (1985) Confidence limits on phylogenies: an approach using bootstrap. Evolution 39, 783-791.

Felsenstein, J. (1993) PHYLIP (Phylogeny inference package). Version 3.5c. Distributed by the author, Department of Genetics, University of Washington, Seattle.

Imura, Y. (1993) New or little known Carabus and Cychrus (Coleoptera, Carabidae) from the Qinling Mountains in Shaanxi Province, Central China. Elytra. Tokyo 21, $363-377$.

Imura, Y. (1996) A revised classification of the major divisions and subdivisions of Carabus (s. lat.) (Coleoptera, Carabidae). Elytra, Tokyo 24, 1-5.

Imura, Y. (2002) Classification of the subtribe Carabina (Coleoptera, Carabidae) based on molecular phylogeny. Elytra, Tokyo 30, 1-28.

Imura, Y., and Mizusawa, K. (1996) The Carabus of the World, 261 pp., 84 pls., Mushi-sha, Tokyo (In Japanese).

Imura, Y., Su, Z.-H., and Osawa, S. (2000) Phylogeny in the division Archicarabomorphi (Coleoptera, Carabidae) viewed from mitochondrial ND5 gene sequences. Elytra, Tokyo 28, 223-228.

Ishikawa, R. (1978) A revision of the higher taxa of the subtribe Carabina (Coleoptera, Carabidae). Bull. natn. Sci. Mus., Tokyo (A) 4, 45-68.

Ishikawa, R. (1979) A preliminary revision of the Carabogenici of the subtribe Carabina (Coleoptera, Carabidae). Bull. natn. Sci. Mus., Tokyo (A) 5, 95-114.

Kimura, M. (1980) A simple method for estimating evolutionary rate of base substitutions through comparative studies of nucleotide sequences. J. Mol. Evol. 16, 111-120.

Obydov, D. V. (1999) A review of the «Carabus tarbagataicus» species group (Coleoptera: Carabidae). Russian Entomol. J. 8, 5-12.

Saiki, R. K., Gelfand, D. H., Stoffl, S., Scharf, S. T., Higuchi, R., Horn, F. T., Mullis, K. B., and Erlich, H. A. (1988) Primerdirected enzymatic amplification of DNA with thermostable DNA polymerase. Science 239, 487-491.

Saitou, N., and Nei, M. (1987) The neighbor-joining method: a new method for reconstructing phylogenetic trees. Mol. Biol. Evol. 4, 406-425.

Sanger, F., Nicklen, S., and Coulson, A. R. (1977) DNA sequencing with chain-terminating inhibitors. Proc. Natl. Acad. Sci. USA 74, 5463-5468.

Su, Z.-H., Ohama, T., Okada, T. S., Nakamura, K., Ishikawa, R., and Osawa, S. (1996) Phylogenetic relationships and evolution of the Japanese Carabinae ground beetles based on mitochondrial ND5 gene sequences. J. Mol. Evol. 42, 124129.

Su, Z.-H., Tominaga, O., Okamoto, M., and Osawa, S. (1998) Origin and diversification of hindwingless Damaster ground beetles within the Japanese Islands as deduced from mitochondrial ND5 gene sequences (Coleoptera, Carabidae). Mol. Biol. Evol. 15, 1026-1039.

Su, Z.-H., Imura, Y., and Osawa, S. (2001) Evolutionary discontinuity of the carabine ground beetles. J. Mol. Evol. 53, $517-529$.

Thompson, J. D., Higgins, D. G., Gibson, T. J. (1994) CLUSTAL W: improving the sensitivity of progressive multiple sequence alignment through sequence weighting, positionspecific gap penalties and weight matrix choice. Nucleic Acids Res. 22, 4673-4680. 